\title{
Financial Management of Micro-Enterprises in Latvian Fisheries Sector
}

\author{
Inese Biukšāne \\ Institute of Agricultural \\ Resources and Economics \\ Rezekne Academy of \\ Technologies \\ Riga, Latvia \\ inese.biuksane@inbox.lv
}

\begin{abstract}
Latvian fisheries sector in the long term depends on thought-out financial management of enterprises and objective and timely identification of various risks. Sound and innovation- and knowledge-based entrepreneurship can contribute to substantial success and growth. The aim of the research is to assess the financial management of micro-enterprises in the Latvian fisheries sector, at the same time providing recommendations for the need in structural reforms and ensuring sustainable financial stability. Based on the chosen assessment methodology, the skills and opportunities of micro-enterprises in creation of capital structure, distribution of financial resources and return were analysed. The information reflected in the framework of the research can assist the institutions, entrepreneurs and researchers involved in establishment and implementation of fisheries policy to better understand the need in successful financial management to ensure a sustainable operation of the sector.
\end{abstract}

Keywords - fisheries sector, financial analysis, Latvia, micro enterprises, sustainable development.

\section{INTRODUCTION}

In Latvia fisheries sector includes fishery, aquaculture and fish processing. The sectors differ in terms of the specific features of their activities and have different development potential [8]. There are 201 enterprises in the fishery sector that catch fish in the inland waters, the Baltic Sea and the Gulf of Riga, as well as on the high seas. There are 94 enterprises operating in the aquaculture sector that breed fish and crustaceans in ponds, basins and recirculation systems. The fish caught in the territorial waters of the state and on the high seas, as well as freshwater fish bred in aquaculture, are used as raw materials in fish processing. There are 108 enterprises operating in the fish processing sector specialising in the production of canned, smoked and salted fish, production of refrigerated and frozen fish, as well as production of mixed fish products. In Latvia, the fisheries sector is closely related to rational and sustainable use of natural resources and conservation of biological diversity, determined by the EU Common Fisheries Policy [2].

In total, 403 enterprises operate in the fisheries sector, most of which (84\%) are micro enterprises. The total number of employees in the sector was 4.46 thousand employees with an average net salary of 569 EUR [5]. Although the GDP of the fisheries sector in the common Latvian economy is not significant (in 2018 it was less than 1\%), Latvia, unlike most EU Member States, traditionally has a positive foreign trade balance of fisheries products. In 2017, fish products and canned fish were exported to more than 60 countries of the world. The EU countries have maintained their leading positions in the field of exports for several years. The largest export partners are Lithuania, Sweden, Germany, Denmark, the Czech Republic, Poland and Estonia. Using the support of the European Maritime and Fisheries Fund and annually visiting a number of international exhibitions, the enterprises operating in the sector also managed to explore new markets [13], thereby mitigating the consequences caused by the Russian embargo. Competitiveness of the Latvian fisheries sector in the long term depends on sound financial management of enterprises and objective and timely identification of various risks. Sound and innovation- and knowledge-based entrepreneurship can facilitate important success.

Research aim - to assess financial management of the micro-enterprises in the Latvian fisheries sector, at the same time providing recommendations for ensuring sustainable financial stability. To reach the aim, the following work tasks were put forward: 1) to select the most important indicators for the assessment of financial 
management of enterprises; 2) to assess the capital structure established by enterprises, their distribution of financial resources and return.

The research is considered to be innovative, as there are no assessments of the financial management of microenterprises in the Latvian fisheries sector carried out to date. The research provides a broad insight describing the skills and opportunities of enterprises in the sector in relation to formation of capital structure, distribution of financial resources and return. The analysis deals with comparison of micro-enterprises in fishery, aquaculture and fish processing in Latvia. The results of the research can help the institutions, entrepreneurs and researchers involved in establishment and implementation of fisheries policy to understand the need for successful financial management better to ensure a sustainable operation of the sector.

The general scientific research methods, statistical research methods and mathematical methods were used in the research. The author mostly applied analysis and synthesis methods in development of conclusions and proposals. Microsoft Excel programme was used to process and analyse the research results.

\section{MATERIALS AND METHODS}

The research will deal with the analysis of the available information and data on micro-enterprises in the Latvian fisheries sector. According to the international regulation of the EU, an enterprise with maximum 10 employees and an annual turnover or balance not exceeding 2 million EUR corresponds to the status of a micro-enterprise [7].

The financial management of micro-enterprises in the Latvian fisheries sector was viewed from the aspect of capital structure established by the enterprises, distribution of financial resources and return. The assessment was based on financial analysis, in the framework of which the liquidity, solvency, efficiency and profitability of microenterprises was viewed. In general, there were 8 indicators selected: Fixed Assets Turnover Ratio [9], Productivity of Labour [4], Total Liquidity Ratio [1], Total Assets Turnover Ratio [11], Debt to Equity Ratio [6], Return on Sales Ratio (ROS) [3], Return Assets Ratio (ROA) [12], Return on Equity Ratio (ROE) [10]. Availability of data and their quality determined the period of analysis from 2005 to 2018.

\section{RESULTS AND DISCUSSION}

The number of micro-enterprises in the fisheries sector has increased by $62 \%$ since 2005 , reaching 339 enterprises in 2018. The amount of micro-enterprises in the aquaculture sector increased the most (3 times; in 2018 there were 90 enterprises), which can be largely explained by the availability of EU funds for aquaculture development. In fishery and fish processing, the number of micro-enterprises grew at a slower rate (by 30\% and 63\%, accordingly) reaching 184 fishery and 65 fish processing enterprises in 2018.

Micro-enterprises in the Latvian fisheries sector are generally not considered as capital-intensive enterprises
(Fig. 1). Fishery enterprises are considered to be less capital intensive, and only then followed by fish processing enterprises. On the other hand, enterprises operating in the aquaculture sector can be assessed as capital-intensive enterprises, which means that the enterprises need significant capital investments to produce aquaculture products. The capital intensity of fixed assets decreased in all the sectors, indicating that enterprises make maximum use of the production means available to them in the production process and start to use more contemporary and powerful technologies for their renewal.

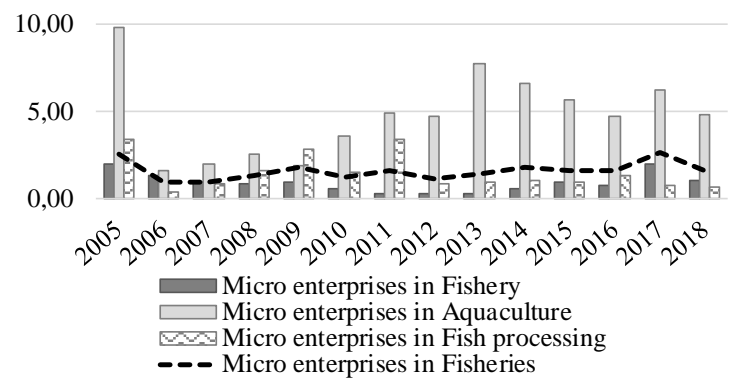

Fig. 1. Fixed Asset Capacity Ratio of the micro-enterprises in the Latvian fisheries sector in 2005-2018 (coefficient) [calculated and created by the author according to 5]

Since 2005, the number of employees in the microenterprises of the Latvian fisheries sector has decreased by -36\%: from 1.99 thousand employees in 2005 to 1.27 thousand employees in 2018. Productivity of Labour in the micro-enterprises of the sector cannot be assessed as high (Fig. 2). Currently, the highest productivity is observed in fish processing - on average 20.64 thousand EUR per employee, followed by fishery with 20.37 thousand EUR per employee and aquaculture with 14.75 thousand EUR per employee. Since 2005, Productivity of Labour has improved in all the sectors, especially in fish processing. Productivity of Labour in the enterprises operating in the sector can be improved by promoting increase in knowledge and skills of employees, as well as by providing favourable working conditions and implementing binding motivation measures.

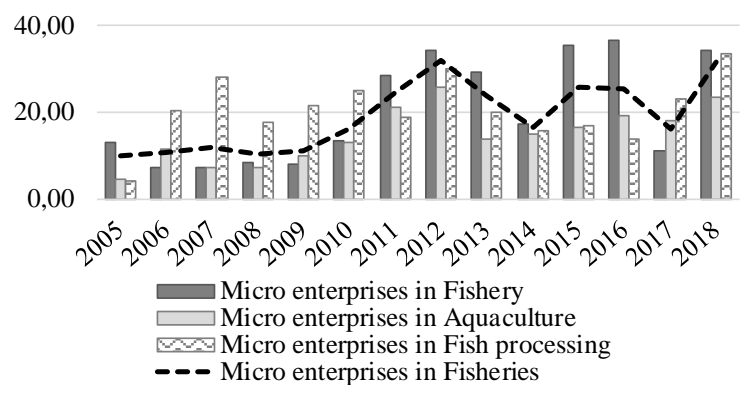

Fig. 2. Productivity of Labour of the micro-enterprises in the Latvian fisheries sector in 2005-2018 (thousand EUR) [calculated and created by the author according to 5]

The liquidity of micro-enterprises in the Latvian fisheries sector can be assessed as optimal, except for certain reporting years (Fig. 3). Total Liquidity Ratio shows that enterprises in the sector as a whole have no problem to cover their short-term liabilities with their available current assets. Higher liquidity was observed in 
fishery and aquaculture enterprises. Fish processing enterprises, on the other hand, stood out with low liquidity (Total Liquidity Ratio on $<1$ ), which indicates short-term financial problems. Currently the micro-enterprises of the sector show a tendency to improve their liquidity. To ensure liquidity, it is desirable to finance short-term liabilities with current assets.

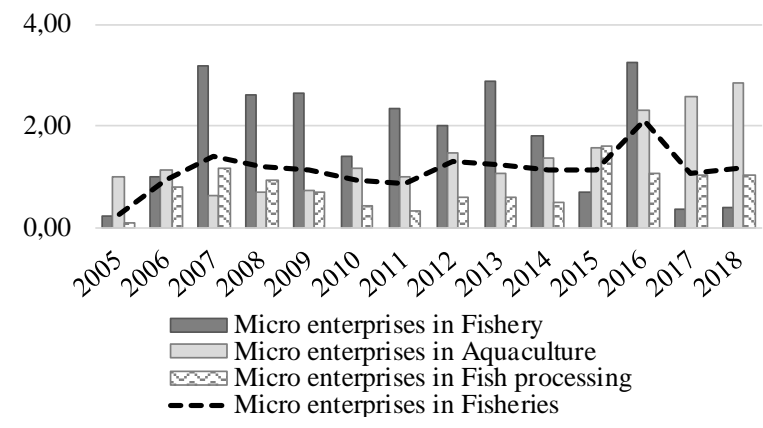

Fig. 3. Total Liquidity Ratio of the micro-enterprises in the Latvian fisheries sector in 2005-2018 (coefficient) [calculated and created by the author according to 5$]$

Micro-enterprises in the Latvian fisheries sector did not use the assets at their disposal effectively enough to generate net turnover (Fig. 4). This was particularly observed in aquaculture enterprises, suggesting that these enterprises have made considerable investments in their assets while failing to contribute to sufficient turnover. The best asset turnover took place in fishery enterprises. Asset turnover has improved in all enterprises of the sector since 2005. In order to be able to contribute to the asset turnover, the enterprises of the sector have to find a possibility to increase their turnover or to dispose a part of their assets which are unfit for production.

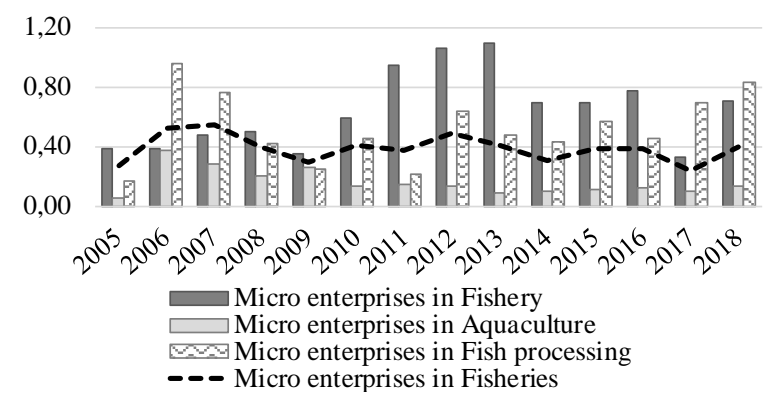

Fig. 4. Total Assets Turnover Ratio of the micro-enterprises in the Latvian fisheries sector in 2005-2018 (coefficient) [calculated and created by the author according to 5 ]

Micro-enterprises in the Latvian fisheries sector as a whole created an unbalanced capital structure (Fig. 5). Enterprises used a lot of debenture capital, failing to correlate it with equity. A particularly unbalanced capital structure was observed for micro-enterprises in the aquaculture sector, where the total liabilities were several times higher than equity, thus exposing them to high financial risks. On the other hand, micro-enterprises operating in the fish processing sector showed negative equity in some reporting years due to accumulated and newly created losses. This, in turn, suggests potential financial difficulties. The micro-enterprises of the sector can improve their financial balance by establishing a wellconsidered and balanced structure of equity and debenture capital. This can also be achieved at the national level by setting maximum admissible ceilings of financial equilibrium at which enterprises in the sector can receive funding from EU financial instruments, government and credit institutions.

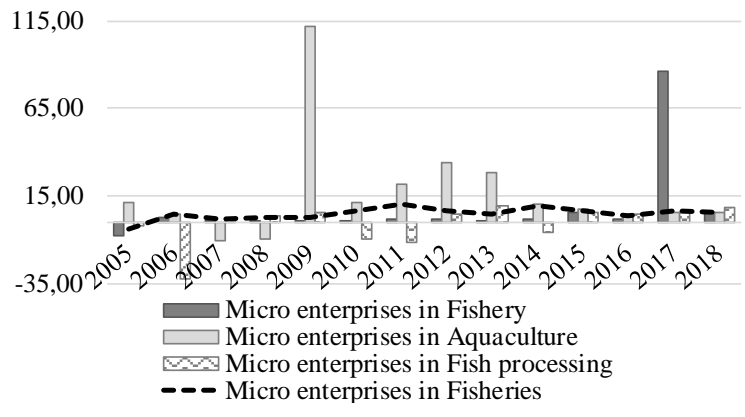

Fig. 5. Debt to Equity Ratio of the micro-enterprises in the Latvian fisheries sector in 2005-2018 (coefficient) [calculated and created by the author according to 5]

The economic activity of micro-enterprises in the Latvian fisheries sector is generally assessed as financially profitable, but not in all reporting years and for all enterprises (Fig. 6). Fishery enterprises are considered to be the most profitable micro-enterprises. Economic activity was not sufficiently profitable in fish processing and aquaculture enterprises.

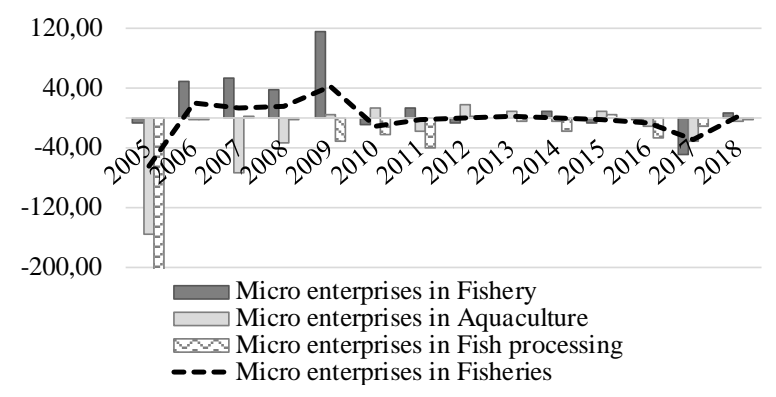

Fig. 6. Return on Sales Ratio of the micro-enterprises in the Latvian fisheries sector in 2005-2018 (\%) [calculated and created by the author according to 5]

The economic profitability of micro-enterprises in the Latvian fisheries sector cannot be assessed unequivocally either (Fig. 7). The largest return on invested assets was generated by micro-enterprises in the fishery sector, but not in all the reporting years. Micro-enterprises in the fish processing sector were less profitable. Enterprises in the sector have made both profits and losses, which indicates various problems in the internal and external environment of enterprises. 


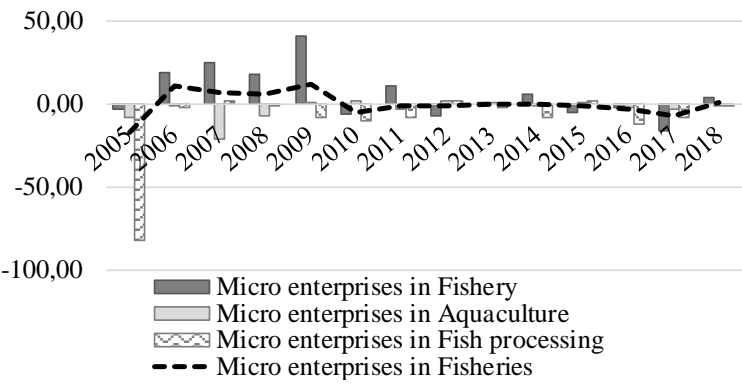

Fig. 7. Return on Assets Ratio of the micro-enterprises in the Latvian fisheries sector in 2005-2018 (\%) [calculated and created by the author according to 5]

A similar situation is observed in relation to financial profitability (Fig. 8). The efficiency of use of the invested capital for micro-enterprises in the Latvian fisheries sector generally can be assessed as good, but not in all the reporting years. Micro-enterprises operating in the aquaculture sector obtained the highest return on their equity, while micro-enterprises operating in the fishery sector obtained the lowest return.

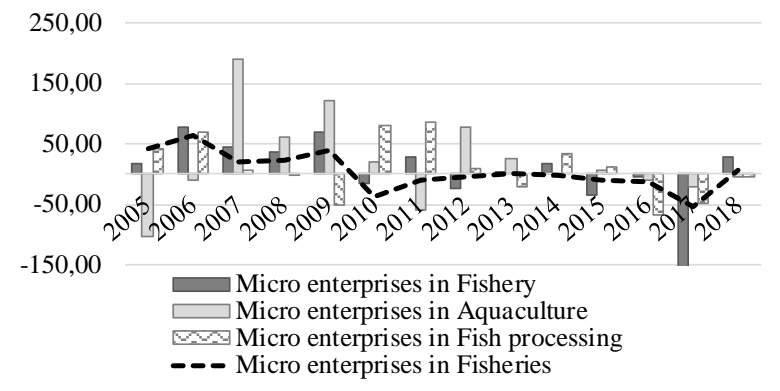

Fig. 8. Return on Equity Ratio of the micro-enterprises in the Latvian fisheries sector in 2005-2018 (\%) [calculated and created by the author according to 5]

The financial management of micro-enterprises operating in the Latvian fisheries sector can be improved by complying with several financing rules, using production resources available to the enterprises efficiently and rationally, at the same time providing for proportionate investments in their renewal and education of workforce. It is not mandatory to follow the financing conditions, but it is desirable from the aspect of sustainable financial stability and ensuring competitiveness.

\section{CONCLUSIONS}

The financial management of micro-enterprises in the Latvian fisheries sector was viewed from the aspect of capital structure created by the enterprises, distribution of financial resources and return, based on application of financial analysis. The evaluation process included 8 indicators, which enabled analysing the liquidity, solvency, efficiency and profitability of micro-enterprises in the fisheries sector. The applied methodology provides the opportunity to understand the need in structural reforms to ensure sustainable financial stability and competitiveness.

Micro-enterprises operating in the Latvian fisheries sector are generally not considered as capital-intensive enterprises (except for enterprises in the aquaculture sector). Although enterprises try to make the most of production means available to them in the production process and use more contemporary and powerful technologies to renew them, the enterprises in the sector do not stand out with high productivity and load of production technologies. Low Productivity of Labour in aquaculture can be explained by lack of knowledge and experience, but in fish processing - with insufficient level of mechanization and automation. In turn, the low production technology load in aquaculture can be related to small production volumes in the fragmented market and the existing competition. Although micro-enterprises in the sector have optimal liquidity (except for enterprises in the fish processing sector), they may face financial difficulties due to an unbalanced capital structure. Enterprises use a lot of debenture capital, which is not commensurate with their equity. The economic activity of enterprises in the sector is not profitable enough, suggesting various problems in the internal and external environment of the enterprises.

The financial management of micro-enterprises operating in the Latvian fisheries sector can be improved by creating a sound and balanced capital structure and distribution of financial resources, while paying attention to rational and efficient use and renewal of resources.

\section{REFERENCES}

[1] A. Gasior, "Financial liquidity analysis of CSR based Capital Group Zywiec SA”, Amfiteatru Economic, vol. 15(7), pp. 784-801, 2013.

[2] Agriculture Ministry, "Rīcības programma Zivsaimniecības attīstībai 2014.-2020. gadam (Operational Programme for Development of Fisheries 2014-2020)”, 130, 2014 (In Latvian).

[3] B. Bayaraa, "Financial Performance Determinants of Organizations: The Case of Mongolian Companies”, Journal of

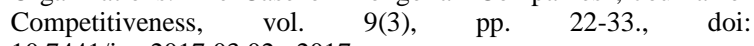
10.7441/joc.2017.03.02., 2017.

[4] B. Walheer, "Labor productivity and technology heterogeneity", Journal of Macroeconomics, vol. 68, 103290, 2021.

[5] Central Statistical Bureau, Database. [Online]. Available: http://data.csb.gov.lv/pxweb/en/?rxid=cdcb978c-22b0-416a-aaccaa650d3e2ce0. [Accessed: April 4, 2021] (restricted access data).

[6] D. Hertina, A.F. Pranata, R.E. Aulia, "The influence of current ratio, debt to equity ratio and company size on return on assets”. Turkish Journal of Computer and Mathematics Education, vol. 12(8), pp. 1702-1709, 2021.

[7] European Commission, “Commission Regulation (EU) No 651/2014 declaring certain categories of aid compatible with the internal market in application of Articles 107 and 108 of the Treaty”, Official Journal of the European Union, L 187/1, 78, 2014.

[8] I. Biukšāne, "Latvian fisheries sector cluster", International Multidisciplinary Scientific GeoConference Proceedings, vol. 18 (5.4.), pp. 465-472, doi: 10.5593/sgem2018/5.4/S23.059, 2018.

[9] L.G.V. Springate, Predicting the Possibility of Failure in a Canadian Firm: A Discriminant Analysis. Canada: Simon Fraser University, 164, 1978.

[10] M. Branten, J. Alver, "Profitability Measurement and Analysis in Estonian Business Practice”, Proceedings of the 5th International Conference on Accounting, Auditing, and Taxation (ICAAT 2016), vol. 27, pp. 8-22, 2016.

[11] M. Dimitric, I.T. Zikovic, A.A. Blecich, "Profitability determinants of hotel companies in selected Mediterranean countries", Economic Research-Ekonomska Istrazivanja, vol. 32(1), pp. 19771993, doi: 10.1080/1331677X.2019.1642785, 2019.

[12] R.S. Njotoprajitno, "Effect of Return on Asset, Return on Equity, Net Profit Margin, Debt to Asset Ratio and Debt to Equity Ratio to 
Environment. Technology. Resources. Rezekne, Latvia Proceedings of the $13^{\text {th }}$ International Scientific and Practical Conference. Volume 1, 38-42

Dividend Payout Ratio of Public Companies Listed in Sharia Securities List in Indonesia Stock Exchange 2009-2012”, 2nd World Conference on Islamic Thought \& Civilization Proceedings, pp. 1070-1086, 2014.
[13] Rural Support Service, Database. [Online]. Available: http://lad.gov.lv/lv/. [Accessed: April 4, 2021] (restricted access data) 